\title{
Degradation of the cellulosic key chromophores 2,5- and 2,6- dihydroxyacetophenone by hydrogen peroxide under alkaline conditions. Chromophores in cellulosics, XVII
}

\author{
Nele S. Zwirchmayr • Ute Henniges • Markus Bacher • Takashi Hosoya • \\ Heidemarie Reiter • Martin Spitzbart • Thomas Dietz • Klaus Eibinger • \\ Wolfgang Kreiner • Arnulf Kai Mahler • Heribert Winter • Thomas Röder • \\ Antje Potthast - Thomas Elder - Thomas Rosenau $(\mathbb{D}$
}

Received: 26 March 2018/Accepted: 29 April 2018/Published online: 17 May 2018

(C) The Author(s) 2018

\begin{abstract}
The dihydroxyacetophenones 2,5-dihydroxyacetophenone (2,5-DHAP) and 2,6-dihydroxyacetophenone (2,6-DHAP) belong to the key chromophores in cellulosic materials. The pulp and paper industry targets these key chromophores in their bleaching sequences to obtain brighter products. 2,5DHAP and 2,6-DHAP were degraded with hydrogen peroxide in alkaline media, similar to conditions of peroxide bleaching ( $\mathrm{P}$ stage) in industrial pulp bleaching. Degradation product analyses were
\end{abstract}

Electronic supplementary material The online version of this article (https://doi.org/10.1007/s10570-018-1817-0) contains supplementary material, which is available to authorized users.

N. S. Zwirchmayr · U. Henniges · M. Bacher ·

A. Potthast · T. Rosenau ( $\bowtie)$

Division of Chemistry of Renewable Resources,

Department of Chemistry, University of Natural

Resources and Life Sciences, Muthgasse 18, 1190 Vienna,

Austria

e-mail: thomas.rosenau@boku.ac.at

T. Hosoya

Graduate School of Life and Environmental Sciences,

Kyoto Prefectural University, Shimogamo-hangi-cho

11-5, Sakyo-ku, Kyoto-shi, Kyoto, Japan

H. Reiter · M. Spitzbart

Mondi Uncoated Fine \& Kraft Paper GmbH, Marxergasse 4A, 1030 Vienna, Austria performed by GC-MS and NMR. The degradation reaction starts by loss of acetic acid originating from the acetyl moiety of the dihydroxyacetophenones (Baeyer-Villiger rearrangement). Further reaction steps involve introduction of another hydroxyl group at C-1 (previously acetyl bearing), and further oxidation of the resulting trihydroxybenzene to quinone intermediates which are ultimately degraded to a mixture of low-molecular weight carboxylic acids.

T. Dietz

Evonik-Degussa, Rodenbacher Chaussee 4, 63457 Hanau-Wolfgang, Germany

K. Eibinger

Zellstoff Pöls AG, Dr. Luigi-Angeli-Str. 9, 8761 Pöls, Austria

W. Kreiner · A. K. Mahler · H. Winter

SAPPI Papier Holding GmbH, Brucker Str. 21,

8101 Gratkorn, Austria

T. Röder

Lenzing AG, Werkstraße 2, 4860 Lenzing, Austria 


\section{Graphical Abstract}

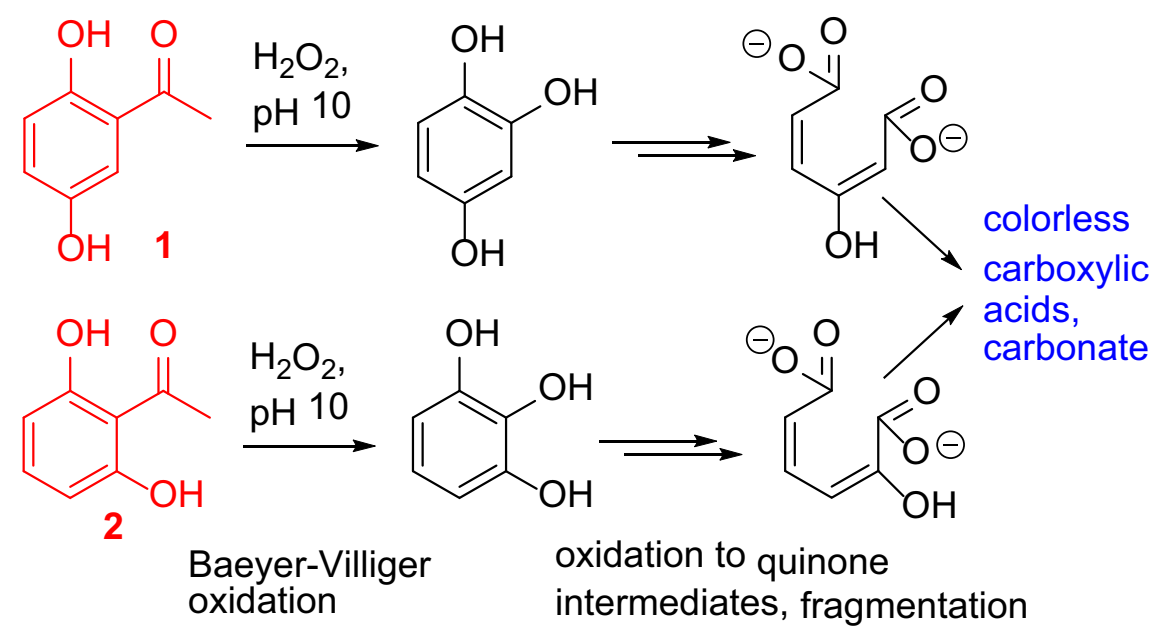

Keywords Cellulose - Chromophores - Yellowing Brightness - Bleaching · Peroxide bleaching · Quinones · Dihydroxyacetophenones

\section{Introduction}

Chromophores in cellulosic materials are survivors of pulp bleaching or are being (re)formed in aged samples. They are present in very low amounts, often as low as ppm to ppb values. Although the amounts are minute, the chromophores' high extinction coefficient makes them immediately visible to the human eye (Schedl et al. 2016). For the pulp and paper industry this results in a need to improve bleaching sequences in order to obtain brighter products with little tendency toward discoloration or "brightness reversion" upon aging. At the same time, also the reduction of bleaching costs and chemical consumption is a crucial aspect of chromophore and bleaching research. The determination of well-defined cellulosic chromophores has been made possible by the CRI (chromophore release and identification) method (Rosenau

T. Elder

USDA Forest Service, Southern Research Station, 521

Devall Dr., Auburn, AL 36849, USA

T. Rosenau

Johan Gadolin Process Chemistry Centre, Åbo Akademi University, Porthansgatan 3, Åbo, Turku 20500, Finland et al. 2004; Korntner et al. 2015). Dihydroxyacetophenones form part of the key chromophores detected in aged pulp and cellulose. The two most important dihydroxyacetophenones in the key chromophore "family" are the constitutional isomers 2,5dihydroxyacetophenone (2,5-DHAP, 1) (Schedl et al. 2016) and 2,6-dihydroxyacetophenone (2,6-DHAP, 2) (Rosenau et al. 2004). Of these two isomers, 2,5DHAP is the stronger one by Vis absorption. Both $\mathbf{1}$ and 2 match the other key chromophores'-2,5dihydroxy-1,4-benzoquinone (DHBQ) and 5,8-dihydroxy-[1,4]-naphthoquinone (DHNQ)-behavior in reaction conditions encountered in chemical pulp bleaching. Moderate solubility in aqueous environment and high stability towards oxidants are among the well-known characteristics of DHBQ, DHNQ, and the DHAP isomers (Hosoya et al. 2013a, b). The key chromophores' characteristic passivity and easy reformation upon aging originates in their remarkable molecular structure. Hydroxyl groups in immediate proximity to carbonyl functions result in H-bonding in acidic and solid state. In alkaline media, deprotonation results in delocalized double bonds and increased stabilization, as depicted in Scheme 1. The orthoquinoid forms $\mathbf{1}^{\prime}$ and $\mathbf{2}^{\prime}$ (Scheme 1), which in a way "anticipate" the quinoid state, are the reason why the compounds are much less prone to oxidation than one would reasonably expect from their structure as phenols. This stabilization effect is especially important when bleaching at alkaline $\mathrm{pH}$, as in a peroxide stage (P stage). Traditional industrial bleaching agents 


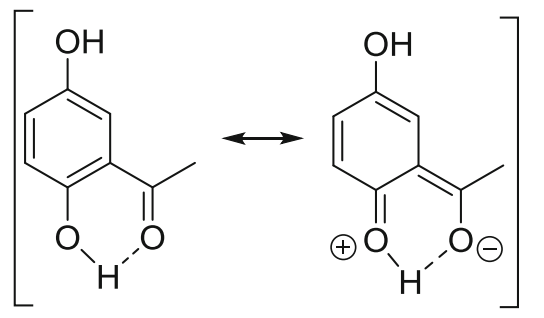

2,5-DHAP, 1<smiles></smiles><smiles>Oc1cccc2c1OB1O[C@H]2Cc2cccc(O)c21</smiles>

2,6-DHAP, 2<smiles>C=CC=C</smiles><smiles></smiles><smiles>CC(O)=C1C=C([O-])C=CC1=O</smiles><smiles>CC(C)C(=O)c1cc([O-])ccc1[O-]</smiles><smiles>CC(C)=C1C=C([O-])C=CC1=O</smiles><smiles>CC(=O)C1=CC([O-])C=CC1=O</smiles>

$1 \mathrm{~b}$<smiles>C=CC1=COCc2cccc([O-])c21</smiles><smiles>CC(O)=C1C(=O)C=CC=C1[O-]</smiles><smiles>CC(=O)c1c([O-])cccc1[O-]</smiles><smiles>CCCC=C1C(=O)C=CC=C1[O-]</smiles>

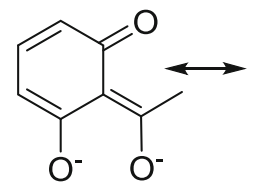<smiles>CC(=O)C1C(=O)C=CCC1=O</smiles>

2b

Scheme 1 2,5-DHAP (1) and 2,6-DHAP (2) and their anions 1a-1b and 2a-2b: stabilization by H-bonds and by resonance

attack localized double bonds, a reaction that is hindered in these chromophores due to precisely these attributes, delocalization of electrons and high symmetry (Rosenau et al. 2011).

In this work, we address the chemical behavior of $\mathbf{1}$ and 2 under conditions of a P bleaching stage (alkaline hydrogen peroxide), with regard to the reaction mechanism of the degradation, and its products, by analogy to previous studies of DHBQ and DHNQ (Hosoya and Rosenau 2013a, b; Zwirchmayr et al. 2017). Kinetic experiments were performed at room temperature and at temperatures as high as $80^{\circ} \mathrm{C}$. This allowed reaction order determination and the construction of Arrhenius plots for the determination of activation energies. The final degradation products were analyzed by GC-MS and NMR experiments.

\section{Experimental section}

Kinetic analysis by UV/Vis measurements at $50{ }^{\circ} \mathrm{C}$, varying excesses of $\mathrm{H}_{2} \mathrm{O}_{2} .2 .5 \mathrm{~mL}$ of the chromophore solution ( $0.4 \mathrm{mM}$ of $\mathbf{1}$ or 2 ) in borax buffer at $\mathrm{pH} 10$ were put into a quartz cuvette. The spectra of $\mathbf{1}$ and $\mathbf{2}$ were recorded from 700 to $200 \mathrm{~nm}$ and the wavelengths of the highest absorption selected $(380 \mathrm{~nm}$ for 1 and $388 \mathrm{~nm}$ for 2). Excess amounts of $\mathrm{H}_{2} \mathrm{O}_{2}(30 \%)$ of 100, 150, 250, 300, 500, 700, 900 and 1100 molar equivalents were added to the cuvette containing the chromophore solution and the degradation was followed at $50{ }^{\circ} \mathrm{C}$ for $5 \mathrm{~min}$. The obtained data was plotted for kinetic analysis and determination of reaction order. 
Kinetic analysis by UV/Vis measurements and temperature variation. $2.5 \mathrm{~mL}$ of the chromophore solution ( $0.4 \mathrm{mM}$ of $\mathbf{1}$ or $\mathbf{2})$ in borax buffer at $\mathrm{pH} 10$ were put into a quartz cuvette. $\mathrm{H}_{2} \mathrm{O}_{2}(30 \%, 300$ molar equivalents) was added and the degradation was followed for $3 \mathrm{~min}$ at the wavelengths of $388 \mathrm{~nm}$ (1) and $380 \mathrm{~nm}(2)$ at constant temperature. The reaction temperatures were varied between 36 and $80{ }^{\circ} \mathrm{C}$.

$G C-M S$ analysis of degradation products. 1 (12 mg, $0.081 \mathrm{mmol})$ and 2 (14 mg, $0.093 \mathrm{mmol})$ were dissolved in in 11.9 and $11.6 \mathrm{~mL}$ of borax buffer at $\mathrm{pH} 10$, respectively. $\mathrm{H}_{2} \mathrm{O}_{2}(30 \%, 200$ molar equivalents) was added. The degradation reaction was quenched with $\mathrm{Na}_{2} \mathrm{~S}_{2} \mathrm{O}_{3}$ after 60 min of reaction time. For GC-MS analyses, the sample $\mathrm{pH}$ was adjusted to neutral by addition of aqueous $\mathrm{HCl} .230$ $\mu \mathrm{L}$ (1) and $235 \mu \mathrm{l}$ (2) of the sample solution were added to a GC vial for freeze-drying. Standard addition, derivatization and sample analysis were performed according to the literature procedure, which also reports the GC-MS operating conditions (Liftinger et al. 2015) The NIST/Wiley 2008 database was used for compound identification.

NMR analyses of the degradation mixture. For NMR analysis, either $1(2.61 \mathrm{mg}, 0.017 \mathrm{mmol})$ or $\mathbf{2}$ (2.60 mg, $0.017 \mathrm{mmol}$ ) were dissolved $0.6 \mathrm{~mL}$ of borax buffer at $\mathrm{pH} 10$. A few drops of $\mathrm{D}_{2} \mathrm{O}$ and 4,4dimethyl-4-silapentane-1-sulfonic acid (DSS) as the internal standard were added and spectra recorded with the use of a solvent suppression technique. $\mathrm{H}_{2} \mathrm{O}_{2}$ (30\%, 5 molar equivalents) was added and ${ }^{1} \mathrm{H}$, HSQC, and $\mathrm{HMBC}$ spectra were recorded 5 min after addition and again after $24 \mathrm{~h}$. Peaks were assigned by NMR databases, by comparison with spectra of standards, and by comparison with the GC-MS results.

Isolation of pyrogallol. $2(0.5 \mathrm{~g}, 3.29 \mathrm{mmol})$ was dissolved in $55 \mathrm{~mL}$ of borax buffer at $\mathrm{pH} 10 . \mathrm{H}_{2} \mathrm{O}_{2}$ (30\%, 2 molar equivalents) was added and the solution stirred for $48 \mathrm{~h}$. A peroxide test (Millipore Sigma, colorimetric test strips) showed no residual peroxide in the reaction solution. The aqueous solution was extracted first with $\mathrm{CH}_{2} \mathrm{Cl}_{2}$ and subsequently with ethyl acetate (EtOAc). The EtOAc extract was dried with $\mathrm{Na}_{2} \mathrm{SO}_{4}$, filtered and the solvent distilled off. The residue was used for column chromatography (solvent gradient: $\mathrm{CH}_{2} \mathrm{Cl}_{2} / \mathrm{CH}_{2} \mathrm{Cl}_{2}+20 \%$ acetonitrile (ACN)/ $\mathrm{ACN}+20 \% \quad \mathrm{CH}_{2} \mathrm{Cl}_{2} / \mathrm{MeOH}+5 \%$ acetic acid). The fractions were analyzed by TLC and the purest fraction used for NMR and GC-MS analysis. For
GC-MS analyses, $1.4 \mathrm{mg}$ of the substance were dissolved in $350 \mu \mathrm{L}$ EtOAc. $100 \mu$ of this solution were put in a GC vial and further diluted with $300 \mu \mathrm{l}$ of EtOAc. Derivatization were performed according to the literature procedure, see above (Liftinger et al. 2015) Methyl $\alpha$-D-galactopyranoside was used as an internal standard. The NIST/Wiley 2008 database was used for compound identification. $\mathrm{R}_{\mathrm{f}}(\mathrm{EtOAc})=0.81$. ${ }^{1} \mathrm{H}$ NMR $\delta\left(\mathrm{CD}_{3} \mathrm{CN} / \mathrm{D}_{2} \mathrm{O}\right): 6.64(1 \mathrm{H}, \mathrm{t}, 4-\mathrm{CH}), 6.45$ (2H, d, 3-CH and 5-CH). ${ }^{13} \mathrm{C} \mathrm{NMR} \delta\left(\mathrm{CD}_{3} \mathrm{CN}\right): 145.4$ (2 and 6-C), 132.3 (1-C), 119.7 (4-C), 107.4 (3 and 5-C). MS (ESI, -), m/z (\%): 133 (15), 239 (37), 342 (13, $\left.\left[\mathrm{M}-\mathrm{H}^{+}\right]\right)$.

\section{Results and discussion}

Kinetic analyses of degradation reactions aim at determining reaction order and activation parameters, and thus allow conclusions as to a possible degradation reaction mechanism. For example, a reaction following pseudo-first order kinetics-with a linear correlation of $\ln [\mathrm{c}]$ vs. time-represents one molecule bleaching agent reacting with one molecule chromophore, if the bleaching agent's concentration can be considered constant throughout. To achieve this condition, the bleaching agent has to be present in large excess in relation to the chromophore. The reaction rate constant $k$ of a pseudo-first order reaction can then be calculated from Eq. 1, where $[\mathrm{DHAP}]_{0}$ is the initial concentration of chromophore and [DHAP] is the concentration of chromophore at the time of measurement (Sandman 2006).

$[$ DHAP $]=[\text { DHAP }]_{0} \mathrm{e}^{-\mathrm{kt}}$

Figure 1 summarizes the kinetic analyses of the degradation of $\mathbf{1}$ and $\mathbf{2}$ by alkaline $\mathrm{H}_{2} \mathrm{O}_{2}$, monitored by UV/Vis. The plots in the top row are constructed by variation of the $\mathrm{H}_{2} \mathrm{O}_{2}$ concentration over several orders of magnitude at a constant temperature of $323.15 \mathrm{~K}$. The reaction rate constant $k$ was calculated from the slope of the linear fit of the data points. The perfect linearity between $\ln [\mathrm{c}]$ and the reaction time indicates pseudo-first order kinetics. The plots in the bottom row of Fig. 1 were obtained from temperature variation $(313.15-353.15 \mathrm{~K})$ at constant $\mathrm{H}_{2} \mathrm{O}_{2}$ concentrations of 300 molecular equivalents (arbitrarily set), these data being used for constructing the 

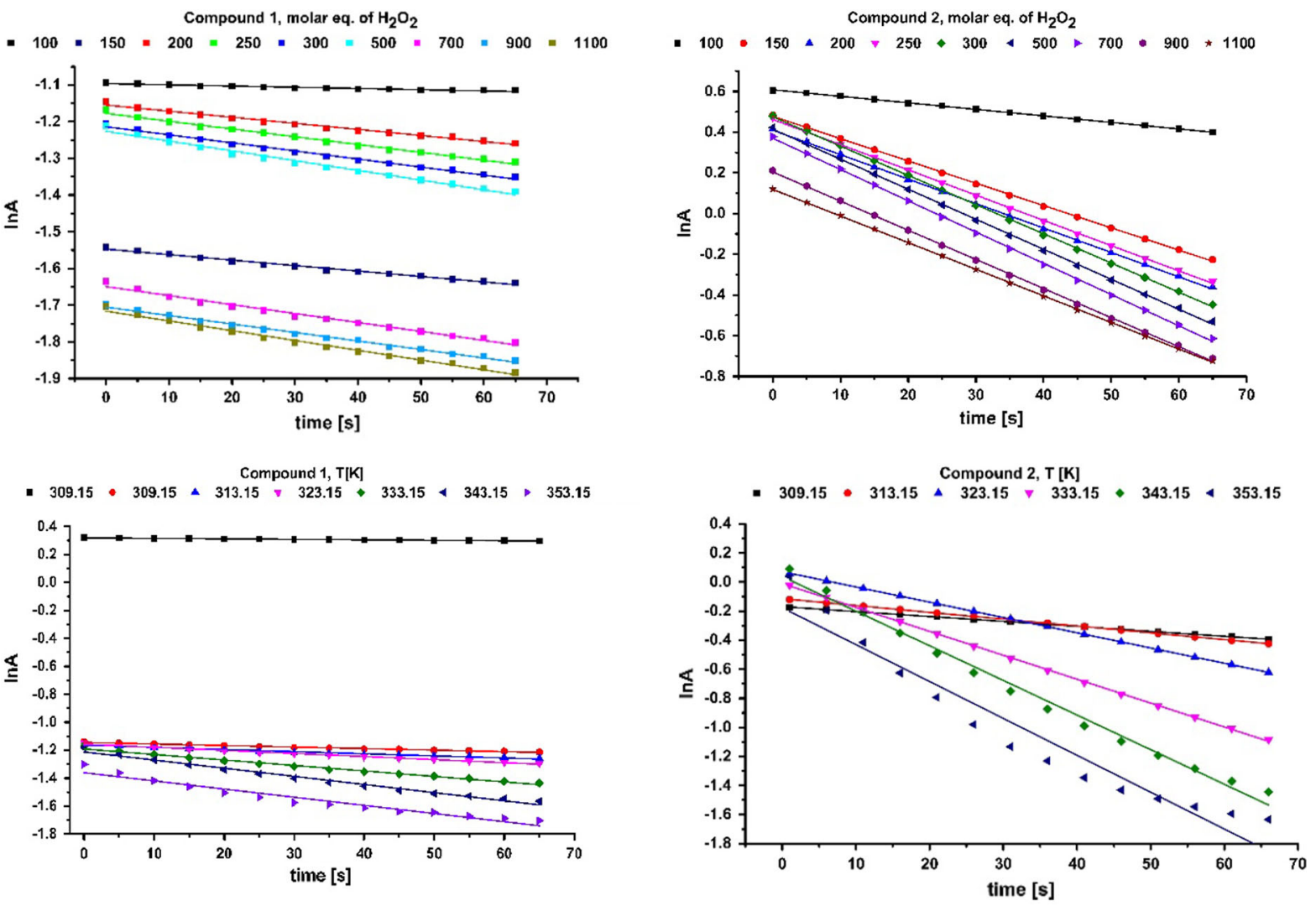

Fig. 1 Kinetic analysis of the degradation of $\mathbf{1}$ and $\mathbf{2}$ by alkaline $\mathrm{H}_{2} \mathrm{O}_{2}$ at $\mathrm{pH} 10$, followed by UV/Vis measurements. Top: Variation of the $\mathrm{H}_{2} \mathrm{O}_{2}$ concentration between 100 and 1100 molar equivalents at a constant temperature of $323.15 \mathrm{~K}$ for the

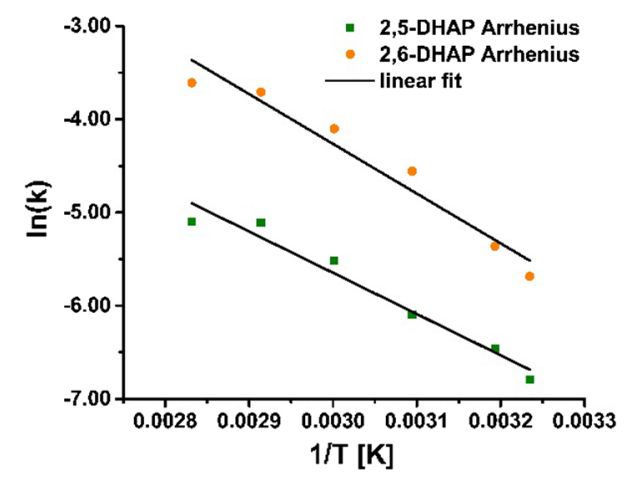

Fig. 2 Arrhenius plots for the degradation of 2,5-DHAP (1) and 2,6-DHAP (2) by $\mathrm{H}_{2} \mathrm{O}_{2}$

Arrhenius plots. All data were recorded at the wavelength of the highest Vis absorption, i.e. $380 \mathrm{~nm}$ for $\mathbf{1}$ and $388 \mathrm{~nm}$ in the case of $\mathbf{2}$.

The Arrhenius plots for the degradation of $\mathbf{1}$ and $\mathbf{2}$ are presented in Fig. 2, obtained by plotting $\ln (k) v s$.

determination of the reaction rate constant $\mathrm{k}$ from the slope of the linear fit of the data points. Bottom: Temperature variation (313.15-353.15 K) while the $\mathrm{H}_{2} \mathrm{O}_{2}$ concentration was kept constant at 300 molecular equivalents

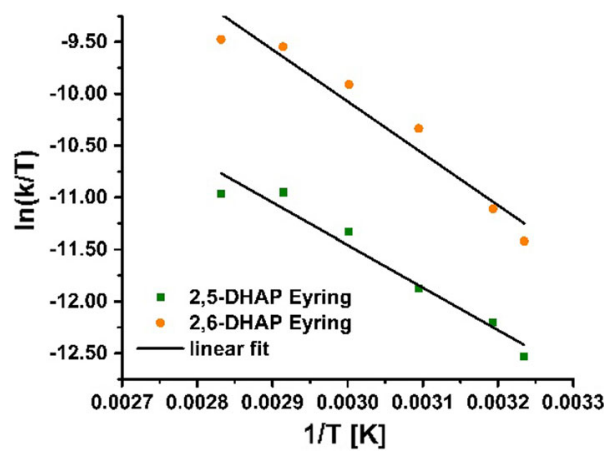

Fig. 3 Eyring plots for the degradation of 2,5-DHAP (1) and 2,6-DHAP (2) by $\mathrm{H}_{2} \mathrm{O}_{2}$

$1 / \mathrm{T}[\mathrm{K}]$. The plots were used for the determination of the Arrhenius activation energy $\mathrm{E}_{\mathrm{A}}$. The related activation parameters $\Delta^{\ddagger} \mathrm{H}^{\circ}, \Delta^{\ddagger} \mathrm{S}^{\circ}$, and $\Delta^{\ddagger} \mathrm{G}^{\circ}$ were determined according to the literature procedure from the Eyring plot, based on the thermodynamic 
formulation of the Eyring equation (Atkins and de Paula 2002). With the $y$-axis being $\ln (k / \mathrm{T})$ and the $\mathrm{x}$-axis $1 / \mathrm{T}, \Delta^{\dagger} \mathrm{S}^{\circ}$ was calculated from the intercept. The Eyring plots for compounds $\mathbf{1}$ and $\mathbf{2}$ are depicted in Fig. 3.

The kinetic data for the alkaline-oxidative degradation of the chromophores $\mathbf{1}$ and $\mathbf{2}$ and the activation parameters calculated from the Arrhenius and Eyring plots are summarized in Tables 1 and 2, respectively.

The activation parameters were comparable for the two isomers $\mathbf{1}$ and 2. This was not necessarily to be expected because hydroquinone derivative 1 would be assumed to undergo oxidation much more readily than resorcinol derivative $\mathbf{2}$. The similarity of the activation parameters indicate that the rate determining step is not directly influenced by the substitution pattern and reactivity of the aromatic ring. This was confirmed by the mechanistic studies below. In similar experiments with DHNQ and DHBQ at $323.15 \mathrm{~K}$, the reaction rate constant $k$ was calculated to be twice as high for DHBQ compared to DHNQ and 2,6-DHAP (0.0261, 0.0115 and 0.0105 , respectively) and the $k$ value of compound 1 (0.00225) was only about a tenth of DHBQ's. This behavior is reflected in the kinetics, with the slope of the curves for compound $\mathbf{1}$ being visibly less steep in the $\ln (\mathrm{A}) v s$. time graphs (Fig. 1). At $323.15 \mathrm{~K}$, activation parameters were comparable between DHNQ, 2,6-DHAP, and 2,5-DHAP. DHBQ, however, had a higher (more positive) value for $\Delta^{\ddagger} \mathrm{H}^{\circ}$ $(15.5 \mathrm{kcal} / \mathrm{mol}$ as compared to $11.1 \mathrm{kcal} / \mathrm{mol}$ for DHNQ, $8.15 \mathrm{kcal} / \mathrm{mol}$ for 2,5-DHAP), and 9.96 $\mathrm{kcal} / \mathrm{mol}$ for 2,6 -DHAP) and higher (more positive) values for $\Delta^{\star} S^{\circ}(-23.6 \mathrm{cal} / \mathrm{K} \mathrm{mol}$ compared to $-33.23 \mathrm{cal} / \mathrm{K} \mathrm{mol}$ (DHNQ), $-45.58 \mathrm{cal} / \mathrm{K} \mathrm{mol}$ (2,5-DHAP), and - $36.92 \mathrm{cal} / \mathrm{K}$ mol (2,6-DHAP)).
$\Delta^{\ddagger} \mathrm{G}^{\circ}$ values were quite close to each other for all four chromophores (between 21.8 and $23.2 \mathrm{kcal} / \mathrm{mol}$ ).

For both compounds $\mathbf{1}$ and $\mathbf{2}, \Delta^{\ddagger} \mathrm{G}^{\circ}$ was about twice as large as $\Delta^{\ddagger} \mathrm{H}^{\circ}$, indicating a large entropic influence. The large negative value of $\Delta^{\ddagger} S^{\circ}$ means a higher degree of order in the rate-determining transition state compared to the starting structures of this elemental step. This is highly indicative of an intermolecular process, involving both the chromophore and the coreactant-in our case $\mathrm{H}_{2} \mathrm{O}_{2}$ or a derived species. A fragmentation reaction, i.e. an intramolecular process, as the rate-determining step would exhibit a positive activation entropy with a less-ordered transition state, which can be ruled out based on the experimental data (Zwirchmayr et al. 2017). The obtained results of a pseudo-first order reaction with similar activation parameters (and thus similar rate-determining steps) for the two chromophores were the base of the mechanistic considerations below.

Degradation reaction mechanism and degradation product analysis

The two chromophores $\mathbf{1}$ and $\mathbf{2}$ are constitutional isomers. The degradation kinetics of $\mathbf{1}$ and $\mathbf{2}$ were comparable, with $k$ and activation parameters of the two compounds being in the same range. From a reaction mixture of the $\mathrm{H}_{2} \mathrm{O}_{2}$ degradation of 2 , it was possible to isolate the intermediate pyrogallol $(4,1,2,3$ trihydroxybenzene), see Scheme 2. To form this compound, the acetyl function in $\mathbf{2}$ had evidently to be replaced by a hydroxyl group. Thus, a BaeyerVilliger type oxidation reaction (BVO) had occurred. Literature offers many examples of acetophenones being oxidized according to this reaction type, with an $\mathrm{OH}$-group being the newly introduced substituent
Table 1 Kinetic data and activation parameters for the degradation of 2,5DHAP (1) by alkaline hydrogen peroxide

\begin{tabular}{lllll}
\hline $\mathrm{T}(\mathrm{K})$ & $k\left(\mathrm{~s}^{-1}\right)$ & \multicolumn{3}{l}{ Activation parameters } \\
\cline { 3 - 5 } & & $\Delta^{*} \mathrm{H}^{\circ}(\mathrm{kcal} / \mathrm{mol})$ & $\Delta^{*} \mathrm{~S}^{\circ}(\mathrm{cal} / \mathrm{K} \mathrm{mol})$ & $\Delta^{\ddagger} \mathrm{G}^{\circ}(\mathrm{kcal} / \mathrm{mol})$ \\
\hline 309.15 & 0.00112 & 8.18 & -45.65 & 22.29 \\
313.15 & 0.00157 & 8.17 & -45.37 & 22.38 \\
323.15 & 0.00225 & 8.15 & -45.58 & 22.88 \\
333.15 & 0.00401 & 8.13 & -45.31 & 23.23 \\
343.15 & 0.00602 & 8.11 & -45.33 & 23.67 \\
$\mathrm{E}_{\mathrm{A}(\text { Arrhenius) }}=8.79 \mathrm{kcal} / \mathrm{mol}$ & & & \\
$\Delta^{\dagger} \mathrm{S}_{\text {(Eyring) }}{ }^{\circ}=-45.56 \mathrm{cal} / \mathrm{K} \mathrm{mol}$ & & \\
\hline
\end{tabular}


Table 2 Kinetic data and activation parameters for the degradation of 2,6DHAP (2) by alkaline hydrogen peroxide

\begin{tabular}{lllll}
\hline $\mathrm{T}(\mathrm{K})$ & $k\left(\mathrm{~s}^{-1}\right)$ & \multicolumn{3}{l}{ activation parameters } \\
\cline { 3 - 5 } & & $\Delta^{\ddagger} \mathrm{H}^{\circ}(\mathrm{kcal} / \mathrm{mol})$ & $\Delta^{\ddagger} \mathrm{S}^{\circ}(\mathrm{cal} / \mathrm{K} \cdot \mathrm{mol})$ & $\Delta^{\ddagger} \mathrm{G}^{\circ}(\mathrm{kcal} / \mathrm{mol})$ \\
\hline 309.15 & 0.00339 & 9.99 & -37.59 & 21.61 \\
313.15 & 0.00469 & 9.98 & -37.41 & 21.70 \\
323.15 & 0.01050 & 9.96 & -36.92 & 21.89 \\
333.15 & 0.01654 & 9.94 & -37.06 & 22.29 \\
343.15 & 0.02453 & 9.92 & -37.27 & 22.71 \\
$\mathrm{E}_{\mathrm{A}(\text { Arrhenius) }}=10.60 \mathrm{kcal} / \mathrm{mol}$ & & \\
$\Delta^{\ddagger} \mathrm{S}_{\text {(Eyring) }}{ }^{\circ}=-37.38 \mathrm{cal} / \mathrm{K} \mathrm{mol}$ & & \\
\hline
\end{tabular}

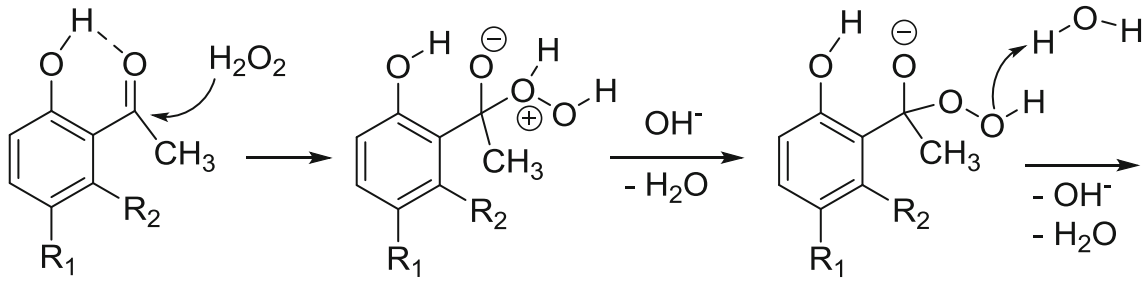

$1 \mathrm{R}_{1}=\mathrm{O}^{-}, \mathrm{R}_{2}=\mathrm{H}$ $2 \mathrm{R}_{1}=\mathrm{H}, \mathrm{R}_{2}=\mathrm{O}^{-}$

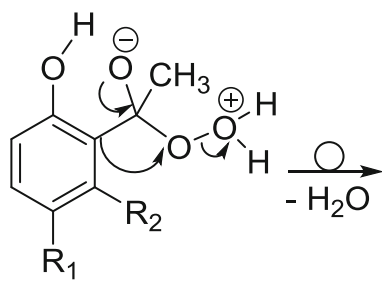<smiles>[R]c1ccc(O)c(OC(C)=O)c1[R2]</smiles><smiles>[R]c1ccc(O)c(O)c1[R2]</smiles>

$$
\begin{aligned}
& 3 \mathrm{R}_{1}=\mathrm{O}^{-}, \mathrm{R}_{2}=\mathrm{H} \\
& 4 \mathrm{R}_{1}=\mathrm{H}, \mathrm{R}_{2}=\mathrm{O}^{-}
\end{aligned}
$$

Scheme 2 Detailed mechanism of the Baeyer-Villiger oxidation/rearrangement as the initial step in the alkaline oxidation of $\mathbf{1}$ and $\mathbf{2}$ by hydrogen peroxide, followed by alkaline saponification of the formed phenyl acetate derivatives

(Grein et al. 2006). From the viewpoint of yield in organic synthesis, hydrogen peroxide is by no means the oxidant of choice in $\mathrm{BVO}$ reactions. Usually, peroxyacids are preferred, and $\mathrm{H}_{2} \mathrm{O}_{2}$ is known to require catalysts for efficient conversion. However, its reputation as an environmentally benign oxidizer has brought $\mathrm{H}_{2} \mathrm{O}_{2}$ more attention recently (Brink et al. 2004; Uyanik and Ishihara 2013). The fact that usually catalysts are involved in BVO reactions with $\mathrm{H}_{2} \mathrm{O}_{2}$ matches the observed kinetics of the chromophore degradation: the bleaching of 2,5-DHAP and 2,6DHAP was slow compared to other key chromophores degraded under similar conditions (Hosoya and Rosenau 2013a, b, Zwirchmayr et al. 2017) and only elevated temperatures of $323.15 \mathrm{~K}$ made kinetic measurements possible at a reasonable time scale of several minutes until full decoloration of the solutions, compared to several hours at room temperature.

Oxidation of pyrogallol on air is known to lead to the red chromophore purpurogallin (Barltrop and Nicholson 1948, Duerckheimer and Paulus 1985). We did not find any purpurogallin in the liquid reaction mixtures in our NMR experiments, but when isolating pyrogallol (4) as an intermediate, the formation of a black, inseparable precipitate in the column during fractionation was evident. From that it can be concluded that purpurogallin is not formed under the applied degradation conditions (alkaline, aqueous 
environment; large excess of $\mathrm{H}_{2} \mathrm{O}_{2}$ ). Instead, oxidation of pyrogallol leads to an ortho-quinone (3hydroxy-1,2-benzoquinone, 6) (Corbett 1966, Juretic et al. 2013). An analogous BVO reaction in the degradation of $\mathbf{1}$ generates hydroxyhydroquinone (3, hydroxyquinol, 1,2,4-trihydroxybenzene). At pH 10, the degradation reaction starts by deprotonation and formation of the anions of 2,5-DHAP (1a) and 2,6DHAP (2a), respectively. Deprotonation occurs always at the 5-OH group in 2,5-DHAP and at the 6-OH group in 2,6-DHAP. These phenolic hydroxyls are more acidic than the 2-OH of which the hydrogen is engaged in the strong hydrogen bond to the neighboring carbonyl oxygen.
The nucleophilic attack of the oxidant hydrogen peroxide at the carbonyl carbon is the rate-determining step, which is followed by the actual Baeyer-Villiger rearrangement into the Criegee intermediate, an ester (phenyl acetate derivative) that is immediately saponified under the alkaline reaction conditions. The outcome of this process is the loss of the acetyl group of the acetophenones as acetate, and a hydroxylation of the aromatic core at the position of the former acetyl moiety (C-1), see Scheme 2.

The isomeric benzenetriols $\mathbf{3}$ and $\mathbf{4}$, the primary oxidation products, were easily further oxidized into the corresponding intermediate quinones (Scheme 3), para-quinone $\mathbf{5}$ and ortho-quinone $\mathbf{6}$, which is in agreement with the literature (Corbett 1970a, b).
$\overbrace{\mathrm{OH}}^{\mathrm{OH}}$

4<smiles>O=C1C(=O)C(O)=CC=C1O</smiles>

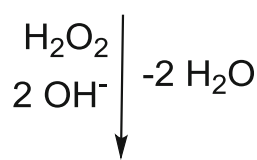<smiles>[O-]CO</smiles><smiles>O=C(O)c1ccccc1O</smiles><smiles>CO</smiles><smiles>Oc1ccc(O)c(O)c1</smiles>
3<smiles>C=C=C</smiles><smiles>O=C1C=CC(O)=CC1=O</smiles>

5 8<smiles>O=C(O)/C=C\C(=O)O</smiles><smiles>O=CC(CO)OO</smiles><smiles>CCC</smiles>

further oxidation $\left(\mathrm{H}_{2} \mathrm{O}_{2}, \mathrm{HO}^{-}\right)$<smiles>CC(=O)[O-]</smiles><smiles>O=C([O-])C1OC1C(=O)[O-]</smiles><smiles>O=C([O-])CC(=O)[O-]</smiles><smiles>O=C([O-])/C=C\C(=O)[O-]</smiles><smiles>O=C([O-])CCC(=O)[O-]</smiles><smiles>O=C[O-]</smiles><smiles>O=C([O-])C(=O)O</smiles><smiles>O=C([O-])CC(O)C(=O)[O-]</smiles>

Scheme 3 Formation of hydroxy-muconic acid derivatives 8 and 9 from the intermediate quinones 6 and 7. Further oxidation produces small carboxylic acids (shown as their anions) as final degradation products, which were confirmed in the reaction mixture 
Table 3 Final products of the degradation of 2,5-DHAP (1) by alkaline $\mathrm{H}_{2} \mathrm{O}_{2}$

\begin{tabular}{|c|c|c|c|c|c|}
\hline $\begin{array}{l}\text { 2,5-DHAP (1) } \\
\text { degrad. prod. }\end{array}$ & $\begin{array}{l}{ }^{1} \mathrm{H} \text { chemical } \\
\text { shift (ppm) }\end{array}$ & $\begin{array}{l}{ }^{13} \mathrm{C} \text { chemical } \\
\text { shift (ppm) }\end{array}$ & GC-MS $m / z$ & $\begin{array}{l}\mathrm{rt} \\
(\min )\end{array}$ & $\begin{array}{l}\text { MW } \\
(\mathrm{g} / \mathrm{mol})\end{array}$ \\
\hline Acetic acid & s, 1.99 & $23.50,181.54$ & - & - & 60.05 \\
\hline Oxalic acid & b & & $190,149,148,147,133,131,117$ & 13.03 & 90.03 \\
\hline Malonic acid & 3.35 & $47.81,177.29$ & $233,150,149,148,147,143,133,131,117$ & 15.16 & 104.06 \\
\hline $\begin{array}{l}\text { Maleic acid } \\
\quad(\text { fumaric acid })\end{array}$ & 6.18 & $130.47,175.42$ & $\begin{array}{l}247,246,245,171,157,156,155,149,148,147,144 \\
\quad 143,133,131,128,127,126117\end{array}$ & 19.18 & 116.07 \\
\hline Succinic acid & 2.65 & $43.63^{\mathrm{a}}$ & $247,172,147,129$ & 18.26 & 118.09 \\
\hline Formic acid & 8.45 & 169.7 & - & - & 46.03 \\
\hline $\begin{array}{l}\text { 2,3-oxirane } \\
\text { dicarboxylic } \\
\text { acid }\end{array}$ & 3.61 & $54.98,174.1$ & - & - & 132.07 \\
\hline Malic acid & $\begin{array}{l}\text { Concentration } \\
\text { too low }\end{array}$ & $\begin{array}{l}\text { Concentration } \\
\text { too low }\end{array}$ & $\begin{array}{l}245,234,233,191,190,189,175,149,148,147,133 \\
\quad 131,117\end{array}$ & 23.22 & 134.09 \\
\hline
\end{tabular}

The ${ }^{1} \mathrm{H}$ and ${ }^{13} \mathrm{C}$ chemical shifts are given in ppm. Wherever possible, ${ }^{13} \mathrm{C}$ shifts were derived from $2 \mathrm{D}$ NMR spectra (HSQC, $\mathrm{HMBC}$ ). GC-MS data is referring to the trimethylsilyl ester derivatives of the substances, minimum threshold $1 \%$. Molecular weights are given for the non-derivatized substance in protonated (acid) form

${ }^{\text {a13 }} \mathrm{C}$ shifts were only partly obtained from 2D NMR spectra

${ }^{\mathrm{b}}$ Substance not detectable by ${ }^{1} \mathrm{H}$ NMR in aqueous medium

Table 4 Final products of the degradation 2,6-DHAP (2) by alkaline $\mathrm{H}_{2} \mathrm{O}_{2}$

\begin{tabular}{|c|c|c|c|c|c|}
\hline $\begin{array}{l}\text { 2,6-DHAP }(2) \\
\text { degrad. prod. }\end{array}$ & $\begin{array}{l}{ }^{1} \mathrm{H} \text { chemical } \\
\text { shift }(\mathrm{ppm})\end{array}$ & $\begin{array}{l}{ }^{13} \mathrm{C} \text { chemical } \\
\text { shift (ppm) }\end{array}$ & GC-MS $m / z$ & $\begin{array}{l}\text { retention time } \\
(\min )\end{array}$ & $\begin{array}{l}\text { MW } \\
(\mathrm{g} / \mathrm{mol})\end{array}$ \\
\hline Acetic acid & 1.93 & $25.43,181.15$ & - & - & 60.05 \\
\hline Oxalic acid & $\mathrm{c}$ & & $219,190,149,148,147,133,131,117$ & 13.04 & 90.03 \\
\hline Malonic acid & 3.36 & $51.36^{\mathrm{b}}$ & $\begin{array}{l}233,150,148,149,147,143,133,131 \\
\quad 117\end{array}$ & 15.16 & 104.06 \\
\hline $\begin{array}{l}\text { Maleic acid (fumaric } \\
\text { acid) }\end{array}$ & 6.03 & a & $\begin{array}{l}245,155,149,148,147,143,133,131 \\
\quad 126,117\end{array}$ & 18.03 & 116.07 \\
\hline Succinic acid & 2.61 & $42.46^{\mathrm{b}}$ & $\begin{array}{l}247,173,172,149,148,147,133,131 \\
\quad 129,117,116\end{array}$ & 18.26 & 118.09 \\
\hline Formic acid & 8.46 & $\mathrm{a}$ & & & \\
\hline $\begin{array}{l}\text { 2,3-Oxirane } \\
\text { dicarboxylic acid }\end{array}$ & 3.35 & 51.36 & & & \\
\hline Malic acid & $\begin{array}{l}\text { concentration } \\
\text { too low }\end{array}$ & $\begin{array}{l}\text { concentration too } \\
\text { low }\end{array}$ & $\begin{array}{l}245,234,233,191,190,189,175,148 \\
\quad 147,133,131,117\end{array}$ & 23.22 & 134.09 \\
\hline
\end{tabular}

The ${ }^{1} \mathrm{H}$ and ${ }^{13} \mathrm{C}$ chemical shifts are given in ppm. Wherever possible, ${ }^{13} \mathrm{C}$ shifts were derived from $2 \mathrm{D}$ NMR spectra $(\mathrm{HSQC}$, HMBC). GC-MS data is referring to the trimethylsilyl ester derivatives of the substances, minimum threshold $1 \%$. Molecular weights are given for the non-derivatized substance in protonated (acid) form

${ }^{\text {a13 }} \mathrm{C}$ shift could not be derived from $2 \mathrm{D}$ NMR spectra

${ }^{\mathrm{b} 13} \mathrm{C}$ shifts were only partly derived from $2 \mathrm{D}$ NMR spectra

${ }^{\mathrm{c}}$ Substance not detectable by ${ }^{1} \mathrm{H}$ NMR in aqueous medium

Compound 5 can also be present in its tautomeric ortho-quinoid form 7, while $\mathbf{6}$ evidently has no paraquinoid tautomers due to its 1,2,3-substitution pattern. The ortho- and para-forms $\mathbf{5}$ and $\mathbf{7}$ are energetically very similar as concluded from computations at the M062X/6-311++g(d,p) level of theory. Their energy difference is only $3 \times 10^{-6} \mathrm{kcal} / \mathrm{mol}$ and thus not 
within the accuracy of chemical determination methods (Cramer 2004).

Degradation of the formed quinones continues by further oxidation by $\mathrm{H}_{2} \mathrm{O}_{2}$, hydrolysis and/or attack of hydroxyl ions. In any case, the muconic acid derivatives 2-hydroxy-muconic acid (8) and 3-hydroxymuconic acid (9) are obtained, a process which is wellknown for the oxidative degradation of trihydroxybenzenes in alkaline media (Boeseken and Engelberts 1931; Corbett 1966a, b). The OH-substituent in $\mathbf{8}$ is able to undergo rearrangement from the position 2 to position 3, resulting in muconic acid derivative 9 (see Scheme 3).

The two muconic acids, in turn, are further degraded into small carboxylic acids according to a complex system of parallel and subsequent reactions. No aldehydes were observed. Although aldehydes could be primary intermediates of quinone-ring opening, their oxidation to carboxylic acids is very fast under the prevailing oxidative conditions (Criegee 1975). An overview of the final degradation products as analyzed by NMR and GC-MS can be found in Table 3 for the degradation of compound $\mathbf{1}$ and in Table 4 for its structural isomer 2 .

\section{Degradation product analysis}

Products of the oxidative degradation of $\mathbf{1}$ and $\mathbf{2}$ were analyzed by GC-MS and NMR spectroscopy measurements. GC-MS used a previously developed analysis method for mixtures of acids, aldehydes, ketoacids and hydroxyacids in complex matrices that is based on oximation/trimethylsilylation. The analytical results agree largely with those from similar bleaching experiments (Juretic et al. 2013; Pillar et al. 2014, 2015). The products are the same for both chromophores, which is a result of the degradation pathway as delineated above, involving an initial Baeyer-Villiger type oxidation with acetic acid as the leaving group, subsequent oxidation of the resulting trihydroxybenzene isomers to the corresponding quinones and further oxidation under ring-fragmentation to muconic acids. The degradation of the latter results in acetic acid, oxalic acid, malonic acid, maleic acid, succinic acid, formic acid, and 2,3-oxiranedicarboxylic acid, with malic acid and oxalacetic acid as intermediates (Andreozzi et al. 2003). Under the prevailing reaction conditions all acids are deprotonated and present in the form of their anions. Apart from the organic low-molecular weight degradation products, carbonate was found as inorganic component. The total of organic degradation products and carbonate account for $66 \%$ of the carbon contained in the starting 2,6-DHAP, and $74 \%$ of starting 2,5DHAP, respectively.

Except for oxalic acid that lacks NMR-active protons under aqueous conditions, and the short-lived intermediates malic acid and oxalacetic acid, all degradation products found in GC-MS were confirmed by in situ ${ }^{1} \mathrm{H}$ NMR measurements, also by spiking with authentic samples. Acetic acid and formic acid were only found by NMR, as they were lost during the GC-MS derivatization process because of the high volatility of their trimethylsilyl derivatives. For details of GC-MS results and NMR shifts see Tables 3 and 4 .

\section{Conclusions}

Oxidative degradation of 2,5-DHAP (1) and 2,6DHAP (2) by alkaline $\mathrm{H}_{2} \mathrm{O}_{2}$ starts with an attack at the acetyl moiety and not at the aromatic ring. The degradation follows of pseudo-first order kinetics. It follows well-established pathways of acetophenone, polyhydroxybenzene and quinone degradation in alkaline and oxidative environments. Starting from the acetophenones, the loss of acetic acid and the introduction of an $\mathrm{OH}$ moiety in its place produces isomeric trihydroxybenzenes, which afford the corresponding quinones upon oxidation. Upon further oxidation and ring fragmentation, muconic acids are obtained which finally yielded mixtures of acetic acid, oxalic acid, malonic acid, maleic acid, succinic acid, formic acid, and 2,3-oxiranedicarboxylic acid, with malic acid and oxalacetic acid being intermediates, as well as carbonate. These products were confirmed by GC-MS and NMR, and their formation is in agreement with previous studies on hydroxybenzene oxidation (Andreozzi et al. 2003). We are reporting that the acetophenones $\mathbf{1}$ and $\mathbf{2}$ can be fully degraded by $\mathrm{H}_{2} \mathrm{O}_{2}$ to colorless products, but also that the bleaching reaction, in terms of faster consumption of the chromophores, greatly benefits from temperatures above r.t. Industrially, these conditions are already applied in P stage bleaching (Zwirchmayr et al. 2017). Especially for the key chromophores with acetophenone structure increased temperature is necessary. 
Albeit chromophoric intermediates were found (orthoand para-quinones 5-7), it is positive for industrial bleaching that purpurogallin —a strongly colored compound formed from pyrogallol upon ambient oxidation (Barltrop and Nicholson 1948) —was not detected, neither by GC-MS nor in NMR spectra of our degradation analyses of $\mathbf{2}$. The colored quinones $\mathbf{5 -}$ 7 are degraded quite easily in alkaline/oxidizing conditions since they lack the distinct stabilization of $\mathbf{1}$ and $\mathbf{2}$. With regard to cellulose bleaching, these results demonstrate that and how the highly stabilized acetophenone key chromophores can be fully degraded to colorless compounds under $\mathrm{P}$ stage conditions.

Acknowledgments Open access funding provided by University of Natural Resources and Life Sciences Vienna (BOKU). The authors would like to thank the Austrian Research Promotion Society (FFG, project 829443) for financial support.

Open Access This article is distributed under the terms of the Creative Commons Attribution 4.0 International License (http:// creativecommons.org/licenses/by/4.0/), which permits unrestricted use, distribution, and reproduction in any medium, provided you give appropriate credit to the original author(s) and the source, provide a link to the Creative Commons license, and indicate if changes were made.

\section{References}

Andreozzi R, Caprio V, Marotta R, Vogna D (2003) Paracetamol oxidation from aqueous solutions by means of ozonation and $\mathrm{H}_{2} \mathrm{O}_{2} / \mathrm{UV}$ system. Water Res 37(5):993-1004

Atkins P, de Paula J (2002) Atkins' Physical Chemistry, 7th edn. Oxford University Press, Oxford

Barltrop JA, Nicholson JS (1948) Oxidation products of phenols. I. The structure of purpurogallin. J Chem Soc 116-120

Boeseken J, Engelberts R (1931) The formation of cis-cis-muconic acid and phenoquinone in the oxidation of phenol with peracetic acid. Proc K Ned Akad Wet 34:1292

Brink GJ, Arends IWCE, Sheldon RA (2004) The Baeyer-Villiger reaction: new developments toward Greener procedures. Chem Rev (Washington, DC, U.S.) 104(Copyright (C) 2017 American Chemical Society (ACS). All Rights Reserved.) 4105-4123

Corbett JF (1966) Hydroxyquinones. I. Reaction of 2-hydroxybenzoquinones with alkaline hydrogen peroxide. J Chem Soc C 24:2308-2311

Corbett JF (1970) Chemistry of hydroxy-quinones. V. Oxidation of 5-alkyl- and 2,5-dialkyl-3-hydroxybenzoquinones in the presence of alkali. J Chem Soc C(14):1912-1916
Corbett JF (1970) Chemistry of hydroxy-quinones. VI. Formation of 2-hydroxy-semiquinones during the autoxidation of benzene-1,2,4-triols in alkaline solution. J Chem Soc C(15):2101-2106

Cramer CJ (2004) Essentials of computational chemistry, 2nd edn. Wiley, Hoboken

Criegee R (1975) Mechanism of ozonolysis. Angew Chem 87(21):765-771

Duerckheimer W, Paulus EF (1985) Mechanism of purpurogallin formation: an adduct from 3-hydroxy-o-benzoquinone and 4,5-dimethyl-o-benzoquinone. Angew Chem 97(3):219-220

Grein FA, Chen C, Edwards D, Crudden CM (2006) Theoretical and experimental studies on the Baeyer-Villiger oxidation of ketones and the effect of $\alpha$-halo substituents. J Org Chem 71(3):861-872

Hosoya T, Rosenau T (2013a) Degradation of 2,5-dihydroxy1,4-benzoquinone by hydrogen peroxide under moderately alkaline conditions resembling pulp bleaching: a combined kinetic and computational study. J Org Chem 78(22):11194-11203

Hosoya T, Rosenau T (2013b) Degradation of 2,5-dihydroxy1,4-benzoquinone by hydrogen peroxide: a combined kinetic and theoretical study. J Org Chem 78(7):3176-3182

Hosoya T, French AD, Rosenau T (2013a) Chemistry of 2,5dihydroxy-[1,4]-benzoquinone, a key chromophore in aged cellulosics. Mini-Rev Org Chem 10(3):309-315

Hosoya T, French AD, Rosenau T (2013b) Chemistry of 5,8dihydroxy-[1,4]-naphthoquinone, a key chromophore in aged cellulosics. Mini-Rev Org Chem 10(3):302-308

Juretic D, Kusic H, Dionysiou DD, Bozic AL (2013) Environmental aspects of photooxidative treatment of phenolic compounds. J Hazard Mater 262:377-386

Korntner P, Hosoya T, Dietz T, Eibinger K, Reiter H, Spitzbart M, Roeder T, Borgards A, Kreiner W, Mahler AK, Winter H, Groiss Y, French AD, Henniges U, Potthast A, Rosenau $\mathrm{T}$ (2015) Chromophores in lignin-free cellulosic materials belong to three compound classes. Chromophores in cellulosics, XII. Cellulose (Dordrecht, Neth.) 22(2):1053-1062

Liftinger E, Zweckmair T, Schild G, Eilenberger G, Boehmdorfer S, Rosenau T, Potthast A (2015) Analysis of degradation products in rayon spinning baths. Holzforschung 69(6):695-702

Pillar EA, Camm RC, Guzman MI (2014) Catechol oxidation by ozone and hydroxyl radicals at the air-water interface. Environ Sci Technol 48(24):14352-14360

Pillar EA, Zhou R, Guzman MI (2015) Heterogeneous oxidation of catechol. J Phys Chem A 119(41):10349-10359

Rosenau, T., A. Potthast, et al. (2011) Chromophores in cellulosics, VI. First isolation and identification of residual chromophores from aged cotton linters. Cellulose (Dordrecht, Neth) 18(6):1623-1633

Rosenau T, Potthast A, Milacher W, Hofinger A, Kosma P (2004) Isolation and identification of residual chromophores in cellulosic materials. Polymer 45(19):6437-6443

Sandman DJ (2006) Modern physical organic chemistry by Eric V. Anslyn and Dennis A. Dougherty. Mol Cryst Liq Cryst 461:147-149 
Schedl A, Korntner P, Zweckmair T, Henniges U, Rosenau T, Potthast A (2016) Detection of cellulose-derived chromophores by ambient ionization-MS. Anal Chem (Washington, DC, U.S.) 88(2):1253-1258

Uyanik M, Ishihara K (2013) Baeyer-Villiger oxidation using hydrogen peroxide. ACS Catal 3(4):513-520
Zwirchmayr NS, Hosoya T, Henniges U, Gille L, Bacher M, Furtmueller P, Rosenau T (2017) Degradation of the cellulosic key chromophore 5,8-dihydroxy-[1,4]-naphthoquinone by hydrogen peroxide under alkaline conditions. J Org Chem 82(21):11558-11565 